\title{
The impact of uncertainty in society on the use of traditional, complementary and alternative medicine: a comparative study on visits to alternative/traditional/folk health care practitioners
}

\author{
Jimpei Misawa ${ }^{1 *}$ (D), Rie Ichikawa ${ }^{1,2}$, Akiko Shibuya ${ }^{1}$, Yukihiro Maeda', Ichiro Arai ${ }^{3}$, Teruyoshi Hishiki ${ }^{4}$ and
} Yoshiaki Kondo ${ }^{1}$

\begin{abstract}
Background: While traditional, complementary and alternative medicine (TCAM) is gaining increased interest worldwide, the structural factors associated with the usage of TCAM at the social level have not been sufficiently explored. We aim to understand the social structure of uncertainty in society that affects the TCAM usage for men and women.

Methods: We studied 32 countries using data from the International Social Survey Programme and the World Bank. In this study, we defined TCAM usage as visits to an alternative/traditional/folk health care practitioner during the past 12 months. We performed a correlation analysis and used a generalized linear model .
\end{abstract}

Results: The prevalence of TCAM usage in terms of visits to practitioners was $26.1 \%$ globally, while usage varied across the 32 countries. Generalized linear models showed that unemployment rate was associated with the prevalence of TCAM usage in terms of visits to practitioners.

Conclusions: At the social-structural level TCAM usage involving visits to practitioners was related to job insecurity. Job insecurity led to a decrease in TCAM usage regarding visits to practitioners. These findings suggest that it is necessary to consider the social-structural factors of uncertainty in society when designing health policies related to TCAM.

Keywords: Traditional, complementary and alternative medicine, International social survey Programme, Uncertainty in society, Job insecurity

\section{Background}

Complementary and alternative medicine (CAM) is defined as "a broad domain of resources that encompasses health systems, modalities, and practices and their accompanying theories and beliefs, other than those intrinsic to the dominant health system of a particular society or culture in a given historical period. CAM includes such resources perceived by their users as associated with positive health outcomes. Boundaries within CAM and

\footnotetext{
* Correspondence: j-misawa@umin.net

'Department of Health Care Services Management, Nihon University School of Medicine, 30-1, Oyaguchikami-cho, Itabashi, Tokyo 173-8610, Japan Full list of author information is available at the end of the article
}

between the CAM domain and the domain of the dominant system are not always sharp or fixed" [1]. In recent years, interest in CAM has increased [2, 3]. Moreover, traditional medicine (TM) has always maintained its popularity worldwide [4]. The combination of TM and CAM is called traditional, complementary and alternative medicine (TCAM) $[5,6]$. The importance of studies on the use of TCAM has been emphasised [6]. Existing literature has reported that the prevalence of TCAM usage among adults in some developed countries ranges between 5 and $76 \%[3,7]$. In the United States, the proportion of people using some form of TCAM was $32.3 \%$ in $2002,35.5 \%$ in 2007, and $33.2 \%$ in 2012 (based on age-adjusted data) [8] 
The prevalence of TCAM usage in EU countries also varied widely, between 0.3 and 86\% [9], as well as in Asian countries. According to a national telephone survey conducted in 2001 for the general population in Japan, the proportion of TCAM usage was 76\% [10], and in South Korea, $71.3 \%$ of people reported having had at least one TCAM therapy during the previous 12 months [11]. According to a national health interview survey of the general population in Taiwan in the same year, the proportion of TCAM usage was $31.8 \%$ among men and $22.4 \%$ among women [12]. These results show that the prevalence of TCAM usage varies greatly across countries and that there is a high level of interest in TCAM the world over.

Despite the high interest in TCAM usage overall, previous studies have focused on individual factors and not studied the factors affecting TCAM usage from a macro perspective so far. Among the individual factors, biological determinants have been reported to be related to TCAM usage. Various types of TCAM among various countries are used by women [13-16], middle-aged people [16-19], and people with health issues [16, 20-22]. Furthermore, TCAM usage was found to be related to individual psychological determinants including hope [23], health anxiety [24], and belief in the efficacy of TCAM [25, 26]. In addition to these biological and psychological determinants, TCAM usage is also associated with sociological determinants such as culture and customs that surround the healthcare domain. Educational level [16, 19, 27], income $[21,28,29]$, and residential areas $[21,30,31]$ were found to be associated with TCAM usage.

In the countries where TCAM usage was studied, the social structure was generally related to these individual factors. Indeed, it has been suggested that individual psycho-social factors were affected by the social structure [32]. Furthermore, Gale (2014) has indicated that TCAM was an important social phenomenon [33]. Moreover, it was noted that there was a need to clarify the factors underlying TCAM usage from the perspective of social structures [23]. Additionally, it was indicated that what is considered complementary or alternative care may have country-level variations [34]. Thus, it is necessary to examine the social-structural factors at the cross-country level. However, previous research that elucidated pertinent factors of TCAM usage has largely ignored the effect of social structures on TCAM usage and has focused only on individual factors. Since the global prevalence of TCAM usage varies across countries, it is necessary to examine these rates of prevalence to understand the associated social-structural factors underlying TCAM usage at the social level.

Various social-structural problems exist at the social level that need to be solved. Modern society is filled with uncertainty and risk [35]. For example, uncertain contexts existing within a society may include social inequality, ageing population, and job insecurity. However, with the weakening of various norms, people are forced to manage various uncertainties and risks by themselves [35]. In such uncertain social contexts, people experience various anxieties in their lives [36]. With regard to the relationship between health and uncertainty in society, previous researches have reported that uncertain social contexts, such as social inequality, economic recession, and ageing population are harmful to health [37-39]. Furthermore, previous studies have shown that various anxieties in life, such as job insecurity, adversely affect the health of individuals experiencing them $[40,41]$. Based on these facts, we speculate that people in uncertain social contexts will become sufficiently interested in their own health to cope with uncertainties and risks. TCAM usage can be considered one of the health behaviors. The increased popularity of self-management of health has resulted in an increased interest in TCAM usage [2]. Furthermore, Frass et al. referenced reports on TCAM usage and interests in the US, Europe, and Asia-Pacific countries, and argued that the interest in TCAM has grown over the past decade. Moreover, the general public's attitude toward TCAM is largely positive [3]. Considering this, in uncertain contexts, people will use TCAM due to their growing interest in maintaining their own health. Accordingly, we hypothesize that the social structure of uncertainty in society is positively related to TCAM usage. Furthermore, with regard to interests in health, previous studies have indicated that women are more interested in health and are more likely to search for health-related information than men $[42,43]$. Indeed, as for the relationship between gender and TCAM usage, studies in each country have indicated that women use TCAM more than men [13-16]. Additionally, studies have shown that men and women have different coping styles when exposed to stressful life events, such as unemployment [44, 45]. Thus, we also suppose that the impact of uncertainty in society on TCAM usage varies between genders.

We aim to understand the social structure of uncertainty in society that affects the TCAM usage for men and women. We identify how this social structure of uncertainty contributes to variations in the prevalence of TCAM usage. Clarifying the factors involved in using TCAM from a social-structural point of view, and not from the perspective of individual factors, can help develop social policy about TCAM in the future.

\section{Methods}

\section{Study design and dataset}

We conducted an ecological study using the country as the study unit to better understand global TCAM utilization rates. We also conducted a secondary analysis using an archived dataset from the International Social 
Survey Programme (ISSP): Health and Health Care [46] to determine the prevalence of TCAM usage. The survey was conducted from February 2011 through April 2013 in the countries listed in Table 1 . The sample size was 55,081 . The largest sample size was China $(n=5620)$ and the smallest was the United Kingdom $(n=936)$. When the gross sample size was calculated as the denominator, the response rate was $48.0 \%$ in the total sample. The highest was in South Africa (85.8\%) and the lowest was in Italy (23.4\%). Furthermore, Table 1 briefly demonstrates the survey methods, sampling methods, presence of weighting, and age structure for each country (See codebooks of ISSP [46] for more information on these). In every country, the subjects were randomly sampled from the electoral list or the list of national registrations. The survey methods involved mainly faceto-face interviews and postal surveys. The youngest participant was 15 -years-old, while the oldest was 102years-old. The age structure varied among countries. The survey data weighted to correct for bias included 21 out of 32 countries. However, as there is no weight available for the international comparison on the ISSP among countries, we calculated the age-standardized prevalence of TCAM usage in order to take into consideration the age structure of each country.

Participants in the ISSP survey were asked the following question: "During the past 12 months, how often did you visit or were visited by an alternative/traditional/folk health care practitioner?" They had to select one of the following options: never, seldom, sometimes, often, or very often. We grouped these responses into two values of "uses TCAM" (containing "seldom" to "very often" responses) and "does not use TCAM" (containing "never" responses) in order to calculate the prevalence of TCAM usage in each of the 32 countries. Therefore, the definition of TCAM usage in this study implies visits to an alternative/traditional/folk health care practitioner during the past 12 months; this is referred to as "TCAM practitioner usage" in this study. The data that was analyzed included only those participants for whom there were no missing values for TCAM practitioner usage, sex and age $(n=52$, 592). In Fig. 1, a flow chart demonstrates the process through which TCAM practitioner usage, age, and sex were excluded (Fig. 1). The excluding process for each country has been shown in Additional file 1: Table S1.

We evaluated the social-structural factors of uncertainty in society for each country from a three-fold perspective: inequality, occupation, and population. We employed the Gini index as the inequality perspective, the country's unemployment rate as the occupation perspective, and the ageing rate as the population perspective. The Gini index is an indicator of income inequality within the country. As the value gets closer to 100 , inequality becomes greater. We employed the index because countries with high levels of income inequality are considered uncertain societies. Unemployment rate is an indicator of job insecurity within the country. We relied on the unemployment rate since countries with high levels of job insecurity are considered uncertain societies. Ageing rate is an indicator of population structure within the country. We relied on the ageing rate as the indicator of uncertainty in society since a high proportion of elderly people is related to a small labor force and declining birthrates. The Gini index, unemployment rate, and ageing rate were adopted from the World Bank dataset [47] for the same 31 countries (since data for Taiwan was missing) as those in the ISSP survey data. We used the average values between 2011 and 2013 for these variables. When a country did not have data for this period, we chose the year that is closer to 2011 to 2013 as another year (see Table 2 for details).

We also employed Gross Domestic Product (GDP) per capita as a control variable. In this study, since we conducted an ecological macro analysis at the national level, it is necessary to adjust for the wealth of the country. GDP per capita was also adopted from the World Bank dataset [47]. As for the variable, we adopted the average value between 2011 and 2013, as mentioned above.

\section{Statistical analysis}

We first calculated the age-standardized prevalence of TCAM practitioner usage among the 32 target countries for the entire sample and then by gender. Next, we conducted a correlation analysis (Spearman's rho: $r_{s}$ ) that calculated simple correlation coefficients among the Gini index, unemployment rate, ageing rate, GDP per capita, and the prevalence of TCAM practitioner usage. We conducted a generalized linear model (Gamma distribution with log link function) with the prevalence of TCAM practitioner usage as the outcome variable for the entire sample and by gender as the outcome variables were continuous and skewed [48]. First, model 1, wherein the Gini index, unemployment rate, and ageing rate was incorporated, was analyzed respectively. Next, model 2 , wherein all variables were incorporated, was analyzed. The GDP per capita was controlled in both models. $P$-values of $<0.05$ were considered statistically significant.

\section{Results}

Of the 52,592 participants available in the ISSP survey data, 26.1\% had used TCAM practitioner in the past 12 months (Fig. 2). The prevalence of TCAM practitioner usage in the past 12 months was $22.8 \%$ among men and $28.8 \%$ among women. For the entire sample, 
Table 1 Social survey summary of each of the 32 target countries

\begin{tabular}{|c|c|c|c|c|c|c|c|c|c|c|c|}
\hline Countries & $\begin{array}{l}\text { Date of } \\
\text { Collection }\end{array}$ & $\begin{array}{l}\text { Gross } \\
\text { sample } \\
\text { size }^{\mathrm{a}}\end{array}$ & $\begin{array}{l}\text { Sample } \\
\text { size }\end{array}$ & $\begin{array}{l}\text { Response } \\
\text { rate }^{\mathrm{b}}\end{array}$ & $\begin{array}{l}\text { Min } \\
\text { age }\end{array}$ & $\begin{array}{l}\text { Max } \\
\text { age }\end{array}$ & $\begin{array}{l}\text { Mean } \\
\text { age }\end{array}$ & $\begin{array}{l}\text { Analyzed } \\
\text { sample }\end{array}$ & Survey methods & $\begin{array}{l}\text { Sampling } \\
\text { methods }\end{array}$ & Weight \\
\hline Australia & $\begin{array}{l}\text { May } 2012 \\
- \text { Aug } \\
2012\end{array}$ & 6250 & 1946 & 31.1 & 18 & 97 & 55.1 & 1830 & $\begin{array}{l}\text { Postal survey } \\
\text { (self-completion) }\end{array}$ & $\begin{array}{l}\text { Random } \\
\text { sampling }\end{array}$ & Yes \\
\hline Belgium & $\begin{array}{l}\text { Apr } 2011 \\
- \text { Dec } \\
2012\end{array}$ & 8821 & 3083 & 35.0 & 17 & 95 & 49.7 & 2850 & $\begin{array}{l}\text { Face-to-face interview } \\
\text { (CAPI) and mail survey }\end{array}$ & $\begin{array}{l}\text { Stratified two- } \\
\text { stage random } \\
\text { sampling and } \\
\text { Simple random } \\
\text { sampling }\end{array}$ & Yes \\
\hline Bulgaria & $\begin{array}{l}\text { Aug } 2011 \\
- \text { Sep } \\
2011\end{array}$ & 2275 & 1003 & 44.1 & 18 & 90 & 51.9 & 969 & $\begin{array}{l}\text { Face-to-face (PAPI) } \\
\text { interview }\end{array}$ & $\begin{array}{l}\text { Three stage } \\
\text { random } \\
\text { sampling }\end{array}$ & Yes \\
\hline Chile & $\begin{array}{l}\text { Nov } 2011 \\
- \text { Dec } \\
2011\end{array}$ & 1872 & 1559 & 83.3 & 18 & 99 & 46.5 & 1436 & Face-to-face interview & $\begin{array}{l}\text { Three stage } \\
\text { random } \\
\text { sampling }\end{array}$ & Yes \\
\hline China & $\begin{array}{l}\text { Jun } 2011 \\
- \text { Nov } \\
2011\end{array}$ & 7800 & 5620 & 72.1 & 17 & 97 & 47.8 & 5558 & Face-to-face interview & $\begin{array}{l}\text { Multi-stage } \\
\text { stratified } \\
\text { sampling }\end{array}$ & Yes \\
\hline Taiwan & $\begin{array}{l}\text { Jul } 2011 \text { - } \\
\text { Apr } 2012\end{array}$ & 4424 & 2199 & 49.7 & 18 & 93 & 46.8 & 2196 & $\begin{array}{l}\text { Face-to-face interview (pencil } \\
\text { and paper \& CAPI) }\end{array}$ & $\begin{array}{l}\text { Three-stage } \\
\text { stratified PPS } \\
\text { sampling }\end{array}$ & Yes \\
\hline Croatia & $\begin{array}{l}\text { May } 2011 \\
\text { - Jun } \\
2011\end{array}$ & 2576 & 1210 & 47.0 & 18 & 87 & 45.6 & 1132 & Face to face interview & $\begin{array}{l}\text { Multistage } \\
\text { sampling }\end{array}$ & No \\
\hline $\begin{array}{l}\text { Czech } \\
\text { Republic }\end{array}$ & $\begin{array}{l}\text { Feb } 2012 \\
- \text { Mar } \\
2012\end{array}$ & 3230 & 1804 & 55.9 & 18 & 92 & 47.4 & 1696 & Face-to-face interview & $\begin{array}{l}\text { Four stage } \\
\text { stratified } \\
\text { probability } \\
\text { sampling }\end{array}$ & Yes \\
\hline Denmark & $\begin{array}{l}\text { Jan } 2013 \\
- \text { Mar } \\
2013\end{array}$ & 2500 & 1388 & 55.5 & 18 & 102 & 46.3 & 1364 & $\begin{array}{l}\text { Web based mail survey } \\
\text { (self-completion) }\end{array}$ & $\begin{array}{l}\text { Simple random } \\
\text { sampling }\end{array}$ & No \\
\hline Finland & $\begin{array}{l}\text { Aug } 2011 \\
- \text { Dec } \\
2011\end{array}$ & 2500 & 1340 & 53.6 & 15 & 75 & 46.2 & 1309 & $\begin{array}{l}\text { Postal, paper and pencil } \\
\text { or internet survey } \\
\text { (self-completion) }\end{array}$ & $\begin{array}{l}\text { Systematic } \\
\text { sampling }\end{array}$ & Yes \\
\hline France & $\begin{array}{l}\text { Mar } 2011 \\
- \text { Sep } \\
2011\end{array}$ & 10,000 & 3319 & 33.2 & 18 & 95 & 52.1 & 3025 & Postal survey & $\begin{array}{l}\text { Random equal } \\
\text { probability } \\
\text { sampling }\end{array}$ & Yes \\
\hline Germany & $\begin{array}{l}\text { Apr } 2012 \\
- \text { Sep } \\
2012\end{array}$ & 5103 & 1681 & 32.9 & 18 & 95 & 49.5 & 1632 & $\begin{array}{l}\text { Self-completion questionnaire } \\
\text { (CASI) and face-to-face interview } \\
\text { (CAPI) }\end{array}$ & $\begin{array}{l}\text { Two stage } \\
\text { random } \\
\text { sampling }\end{array}$ & No \\
\hline Israel & $\begin{array}{l}\text { Nov } 2011 \\
-\mathrm{Apr} \\
2012\end{array}$ & 1594 & 1220 & 76.5 & 18 & 92 & 45.8 & 1084 & Face to face interview & $\begin{array}{l}\text { Four stage } \\
\text { stratified } \\
\text { sampling }\end{array}$ & No \\
\hline Italy & $\begin{array}{l}\text { Oct } 2012 \\
- \text { Feb } \\
2013\end{array}$ & 5062 & 1186 & 23.4 & 16 & 92 & 50.7 & 1074 & $\begin{array}{l}\text { Self-completion questionnaire } \\
\text { (paper and pencil) was } \\
\text { delivered by interviewer and } \\
\text { returned by mail }\end{array}$ & $\begin{array}{l}\text { Four stage } \\
\text { stratified } \\
\text { sampling }\end{array}$ & Yes \\
\hline Japan & $\begin{array}{l}\text { Nov } 2011 \\
- \text { Dec } \\
2011\end{array}$ & 1800 & 1306 & 72.6 & 16 & 100 & 50.5 & 1287 & Self-completion & $\begin{array}{l}\text { Two-stage } \\
\text { stratified } \\
\text { random } \\
\text { sampling }\end{array}$ & No \\
\hline $\begin{array}{l}\text { South } \\
\text { Korea }\end{array}$ & $\begin{array}{l}\text { Jun } 2011 \\
- \text { Aug } \\
2011\end{array}$ & 2500 & 1535 & 61.4 & 18 & 94 & 46.0 & 1535 & Face-to-face interview & $\begin{array}{l}\text { Multi-stage area } \\
\text { probability } \\
\text { sampling }\end{array}$ & No \\
\hline Lithuania & $\begin{array}{l}\text { Nov } 2011 \\
- \text { Dec } \\
2011\end{array}$ & 3313 & 1187 & 35.8 & 18 & 87 & 47.7 & 1099 & $\begin{array}{l}\text { Face to face interview/paper } \\
\text { and pencil interview (PAPI), } \\
\text { with visuals }\end{array}$ & $\begin{array}{l}\text { Multistage } \\
\text { stratified } \\
\text { sampling }\end{array}$ & Yes \\
\hline Netherlands & Mar 2011 & 4500 & 1472 & 32.7 & 17 & 97 & 54.0 & 1406 & Postal survey & Simple random & Yes \\
\hline
\end{tabular}


Table 1 Social survey summary of each of the 32 target countries (Continued)

\begin{tabular}{|c|c|c|c|c|c|c|c|c|c|c|c|}
\hline Countries & $\begin{array}{l}\text { Date of } \\
\text { Collection }\end{array}$ & $\begin{array}{l}\text { Gross } \\
\text { sample } \\
\text { size }^{a}\end{array}$ & $\begin{array}{l}\text { Sample } \\
\text { size }\end{array}$ & $\begin{array}{l}\text { Response } \\
\text { rate }^{b}\end{array}$ & $\begin{array}{l}\text { Min } \\
\text { age }\end{array}$ & $\begin{array}{l}\text { Max } \\
\text { age }\end{array}$ & $\begin{array}{l}\text { Mean } \\
\text { age }\end{array}$ & $\begin{array}{l}\text { Analyzed } \\
\text { sample }\end{array}$ & Survey methods & $\begin{array}{l}\text { Sampling } \\
\text { methods }\end{array}$ & Weight \\
\hline & $\begin{array}{l}- \text { Dec } \\
2011\end{array}$ & & & & & & & & & sampling & \\
\hline Norway & $\begin{array}{l}\text { Mar } 2012 \\
- \text { Apr } \\
2012\end{array}$ & 3800 & 1834 & 48.3 & 18 & 77 & 48.3 & 1789 & Postal and web survey & $\begin{array}{l}\text { Random } \\
\text { sampling }\end{array}$ & No \\
\hline Philippines & $\begin{array}{l}\text { Sep } 2011 \\
\text { - Sep } \\
2011\end{array}$ & 3206 & 1200 & 37.4 & 18 & 86 & 42.9 & 1167 & $\begin{array}{l}\text { Face-to-face interviews } \\
\text { with visuals }\end{array}$ & $\begin{array}{l}\text { Multi-stage } \\
\text { Probability } \\
\text { Sampling }\end{array}$ & Yes \\
\hline Poland & $\begin{array}{l}\text { Apr } 2013 \\
- \text { Apr } \\
2013\end{array}$ & 2640 & 1115 & 42.2 & 18 & 88 & 47.8 & 1081 & CAPI & $\begin{array}{l}\text { Multi-stage area } \\
\text { probability } \\
\text { sampling }\end{array}$ & Yes \\
\hline Portugal & $\begin{array}{l}\text { Nov } 2012 \\
-\mathrm{Apr} \\
2013\end{array}$ & 2256 & 1022 & 45.3 & 18 & 93 & 51.6 & 968 & CAPI & $\begin{array}{l}\text { Four stage area } \\
\text { sampling }\end{array}$ & Yes \\
\hline Russia & $\begin{array}{l}\text { Dec } 2011 \\
- \text { Dec } \\
2011\end{array}$ & 3170 & 1511 & 47.7 & 18 & 96 & 48.1 & 1467 & Face-to-face interviews & $\begin{array}{l}\text { Four stage } \\
\text { stratified } \\
\text { probability } \\
\text { sampling }\end{array}$ & Yes \\
\hline Slovakia & $\begin{array}{l}\text { Oct } 2012 \\
- \text { Dec } \\
2012\end{array}$ & 2544 & 1128 & 44.3 & 18 & 92 & 51.9 & 1111 & CAPI with visuals & $\begin{array}{l}\text { Two stage } \\
\text { sampling }\end{array}$ & Yes \\
\hline Slovenia & $\begin{array}{l}\text { Mar } 2011 \\
- \text { Jun } \\
2011\end{array}$ & 1800 & 1082 & 60.1 & 18 & 99 & 48.6 & 1062 & $\begin{array}{l}\text { Personal interviews } \\
\text { (pencil and paper } \\
\text { with visuals) }\end{array}$ & $\begin{array}{l}\text { Two-stage } \\
\text { stratified } \\
\text { random } \\
\text { sampling }\end{array}$ & No \\
\hline $\begin{array}{l}\text { South } \\
\text { Africa }\end{array}$ & $\begin{array}{l}\text { Sep } 2011 \\
- \text { Oct } \\
2011\end{array}$ & 3500 & 3004 & 85.8 & 16 & 95 & 40.6 & 2757 & Face-to-face interview & $\begin{array}{l}\text { Multi-stage } \\
\text { stratified } \\
\text { sampling }\end{array}$ & Yes \\
\hline Spain & $\begin{array}{l}\text { May } 2012 \\
\text { - Jul } 2012\end{array}$ & 4000 & 2712 & 67.8 & 18 & 97 & 49.2 & 2622 & Face-to-face interview & $\begin{array}{l}\text { Two phased, } \\
\text { stratified by } \\
\text { clusters. } \\
\text { Proportional } \\
\text { random } \\
\text { sampling }\end{array}$ & Yes \\
\hline Sweden & $\begin{array}{l}\text { Feb } 2011 \\
\text { - May } \\
2011\end{array}$ & 1966 & 1158 & 58.9 & 18 & 80 & 50.0 & 1087 & Postal survey & $\begin{array}{l}\text { A representative } \\
\text { sample of the } \\
\text { Swedish } \\
\text { population }\end{array}$ & No \\
\hline Switzerland & $\begin{array}{l}\text { Mar } 2011 \\
- \text { Nov } \\
2011\end{array}$ & 2409 & 1212 & 50.3 & 19 & 98 & 48.9 & 1192 & CAPI & $\begin{array}{l}\text { Simple random } \\
\text { sampling }\end{array}$ & No \\
\hline Turkey & $\begin{array}{l}\text { Nov } 2011 \\
- \text { Jan } \\
2012\end{array}$ & 3150 & 1559 & 49.5 & 17 & 92 & 42.1 & 1398 & $\begin{array}{l}\text { Face-to-face interview } \\
\text { with visuals }\end{array}$ & $\begin{array}{l}\text { Multi-stage area } \\
\text { sampling }\end{array}$ & No \\
\hline UK & $\begin{array}{l}\text { Jul } 2011 \text { - } \\
\text { Nov } 2011\end{array}$ & 2260 & 936 & 41.4 & 17 & 97 & 49.7 & 897 & $\begin{array}{l}\text { Face-to-face interview } \\
\text { and postal survey } \\
\text { (self-completion) }\end{array}$ & $\begin{array}{l}\text { Clustered } \\
\text { random } \\
\text { sampling }\end{array}$ & Yes \\
\hline US & $\begin{array}{l}\text { Mar } 2012 \\
\text { - Sep } \\
2012\end{array}$ & 2044 & 1550 & 75.8 & 20 & 89 & 50.0 & 1512 & $\begin{array}{l}\text { Face-to-face interview } \\
\text { with CAPI }\end{array}$ & $\begin{array}{l}\text { Multi-stage area } \\
\text { probability } \\
\text { sample }\end{array}$ & Yes \\
\hline Total & $\begin{array}{l}\text { Mar } 2011 \\
- \text { Mar } \\
2013\end{array}$ & 114,865 & 55,081 & 48.0 & 15 & 102 & 48.3 & 52,592 & & & \\
\hline
\end{tabular}

CAPI Computer-Assisted Personal Interview, PAPI Paper-And-Pencil Interview, PPS Probability Proportional to the Size

${ }^{\text {a }}$ Total number of starting target subjects

${ }^{\mathrm{b}}$ The proportion of number of respondents to gross sample size (\%)

${ }^{\mathrm{C}} \mathrm{A}$ flow chart demonstrates the process through which the TCAM practitioner usage, age, and sex were excluded in Fig. 1 . The excluding process for each country has been shown in Additional file 1: Table S1 


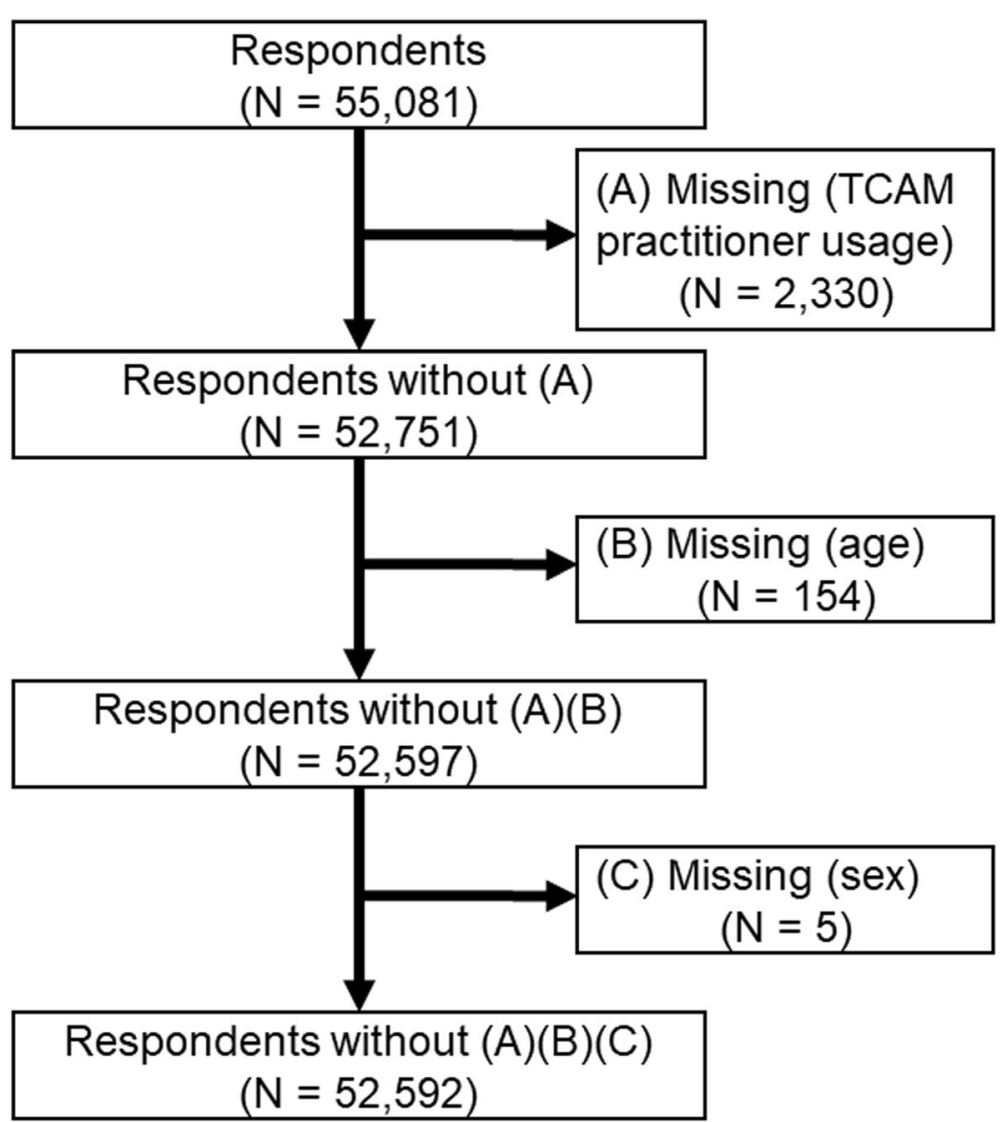

Fig. 1 The flowchart of the process of TCAM practitioner usage, age and gender excluded. Samples with missing information on TCAM practitioner usage, age and sex variables were excluded. Finally, 52,592 samples were analysed

the highest and lowest TCAM practitioner usage prevalence rates were $50.7 \%$ in China and $6.1 \%$ in Poland. For men, the highest and lowest TCAM practitioner usage prevalence rates were $48.6 \%$ in China and $5.7 \%$ in Slovenia. For women, the highest and lowest TCAM practitioner usage prevalence rates were $56.1 \%$ in Philippines and 5.6\% in Poland.

Table 2 shows statistics of the social-structural indicators, with the mean Gini index at 34.6. The mean unemployment rate and ageing rate were 9.1 and $15.2 \%$, respectively. The mean GDP per capita applied as the control variable was $34,344.1$.

Table 3 shows the results of the correlation coefficients between social-structural factors of uncertainty and the prevalence of TCAM practitioner usage for the entire sample and by gender. For the entire sample, we found a statistically significant negative correlation of the prevalence of TCAM practitioner usage with $\mathrm{n}$ the unemployment rate $\left(r_{s}=-0.549, P=0.001\right)$ and the ageing rate $\left(r_{s}=-0.373, P=0.039\right)$. However, a statistically significant correlation was not found between the Gini index and the prevalence of TCAM practitioner usage $\left(r_{s}=0.314, P=0.085\right)$. For men, we found a statistically significant positive correlation of the prevalence of
TCAM practitioner usage with the Gini index $\left(r_{s}=\right.$ $0.400, P=0.026)$, and a statistically significant negative correlation of the prevalence of TCAM practitioner usage with the unemployment rate $\left(r_{s}=-0.435, P=\right.$ $0.015)$ and the ageing rate $\left(r_{s}=-0.420, P=0.019\right)$. For women, we found a statistically significant negative correlation of the prevalence of TCAM practitioner usage with the unemployment rate $\left(r_{s}=-0.610, P<0.001\right)$. However, a statistically significant correlation was not found among the Gini index $\left(r_{s}=0.237, P=0.199\right)$, the ageing rate $\left(r_{s}=-0.299, P=0.102\right)$, and the prevalence of TCAM practitioner usage. GDP per capita was not correlated with the prevalence of TCAM practitioner usage for the entire sample, among men, or among women. Among the social-structural indicators of uncertainty, the Gini index was negatively correlated with the ageing rate $\left(r_{s}=-0.417, P=0.020\right)$.

Table 4 shows the results of the generalized linear model as controlled by GDP per capita for the total sample and by gender. For the entire sample, the Gini index was not related to the prevalence of TCAM practitioner usage in model $1.1(B=0.029, P=0.064)$. However, for the entire sample, the unemployment rate $(B=-0.041$, 
Table 2 Statistics of social structural indicators of the 32 target countries

\begin{tabular}{|c|c|c|c|c|}
\hline Countries & Gini index $^{a}$ & Unemployment rate ${ }^{a}$ & Ageing rate $^{a}$ & GDP per capita $^{a}$ \\
\hline Australia & $34.7^{d}$ & $5.3^{\mathrm{b}}$ & $14.0^{b}$ & $65,863.0^{b}$ \\
\hline Belgium & $27.8^{\mathrm{b}}$ & $7.7^{\mathrm{b}}$ & $17.6^{\mathrm{b}}$ & $46,342.0^{b}$ \\
\hline Bulgaria & $35.6^{\mathrm{b}}$ & $12.2^{b}$ & $18.9^{b}$ & $7622.2^{\mathrm{b}}$ \\
\hline Chile & $47.5^{h}$ & $6.5^{\mathrm{b}}$ & $9.7^{b}$ & $15,359.7^{b}$ \\
\hline China & $42.2^{9}$ & $4.4^{\mathrm{b}}$ & $8.8^{b}$ & $6349.8^{b}$ \\
\hline Taiwan & NA & NA & NA & NA \\
\hline Croatia & $32.4^{\mathrm{b}}$ & $15.6^{\mathrm{b}}$ & $18.0^{\mathrm{b}}$ & $13,783.3^{b}$ \\
\hline Czech Republic & $30.7^{\mathrm{h}}$ & $6.9^{\mathrm{b}}$ & $16.4^{\mathrm{b}}$ & $20,454.4^{b}$ \\
\hline Denmark & $27.9^{\mathrm{b}}$ & $7.4^{\mathrm{b}}$ & $17.5^{\mathrm{b}}$ & $60,484.1^{b}$ \\
\hline Finland & $27.3^{\mathrm{b}}$ & $7.9^{\mathrm{b}}$ & $18.4^{b}$ & $49,281.5^{b}$ \\
\hline France & $32.9^{b}$ & $9.8^{\mathrm{b}}$ & $17.5^{b}$ & $42,400.8^{b}$ \\
\hline Germany & $30.7^{h}$ & $5.5^{\mathrm{b}}$ & $20.8^{b}$ & $45,802.2^{b}$ \\
\hline Israel & $41.4^{f}$ & $6.7^{b}$ & $10.7^{b}$ & $34,169.0^{b}$ \\
\hline Italy & $34.8^{\mathrm{b}}$ & $10.4^{b}$ & $21.2^{b}$ & $36,173.0^{b}$ \\
\hline Japan & $32.1^{c}$ & $4.3^{b}$ & $23.9^{b}$ & $45,742.0^{b}$ \\
\hline South Korea & $31.6^{f}$ & $3.2^{\mathrm{b}}$ & $11.5^{\mathrm{b}}$ & $24,776.2^{b}$ \\
\hline Lithuania & $34.3^{b}$ & $13.5^{b}$ & $17.8^{\mathrm{b}}$ & $14,803.9^{b}$ \\
\hline Netherlands & $27.8^{\mathrm{b}}$ & $6.0^{\mathrm{b}}$ & $16.4^{\mathrm{b}}$ & $51,529.9^{b}$ \\
\hline Norway & $25.8^{\mathrm{b}}$ & $3.2^{\mathrm{b}}$ & $15.4^{b}$ & $101,812.9^{b}$ \\
\hline Philippines & $42.2^{f}$ & $7.0^{\mathrm{b}}$ & $4.3^{b}$ & $2564.9^{b}$ \\
\hline Poland & $32.6^{\mathrm{b}}$ & $10.0^{\mathrm{b}}$ & $14.2^{b}$ & $13,604.8^{b}$ \\
\hline Portugal & $36.2^{\mathrm{b}}$ & $14.8^{b}$ & $19.5^{\mathrm{b}}$ & $21,797.4^{b}$ \\
\hline Russia & $40.5^{b}$ & $5.8^{\mathrm{b}}$ & $13.2^{\mathrm{b}}$ & $15,264.3^{b}$ \\
\hline Slovakia & $26.9^{b}$ & $13.9^{\mathrm{b}}$ & $13.0^{\mathrm{b}}$ & $17,884.5^{\mathrm{b}}$ \\
\hline Slovenia & $25.6^{\mathrm{b}}$ & $9.0^{\mathrm{b}}$ & $17.1^{b}$ & $23,625.2^{b}$ \\
\hline South Africa & $63.4^{e}$ & $24.6^{b}$ & $4.8^{b}$ & $7425.6^{b}$ \\
\hline Spain & $35.8^{f}$ & $24.1^{\mathrm{b}}$ & $17.8^{\mathrm{b}}$ & $29,870.3^{b}$ \\
\hline Sweden & $27.2^{\mathrm{b}}$ & $8.0^{\mathrm{b}}$ & $18.8^{\mathrm{b}}$ & $59,003.5^{b}$ \\
\hline Switzerland & $31.9^{\mathrm{b}}$ & $4.2^{\mathrm{b}}$ & $17.3^{b}$ & $85,688.8^{b}$ \\
\hline Turkey & $40.1^{b}$ & $8.5^{\mathrm{b}}$ & $7.4^{\mathrm{b}}$ & $11,868.1^{b}$ \\
\hline United Kingdom & $32.9^{b}$ & $7.8^{\mathrm{b}}$ & $17.2^{\mathrm{b}}$ & $41,975.7^{b}$ \\
\hline United States & $41.0^{9}$ & $8.1^{b}$ & $13.6^{\mathrm{b}}$ & $51,342.6^{b}$ \\
\hline Mean & 34.6 & 9.1 & 15.2 & $34,344.1$ \\
\hline Standard Deviation & 7.6 & 5.1 & 4.6 & $23,662.0$ \\
\hline Maximum & 63.4 & 24.6 & 23.9 & $101,812.9$ \\
\hline Minimum & 25.6 & 3.2 & 4.3 & 2564.9 \\
\hline
\end{tabular}

${ }^{\mathrm{a}}$ From the World Bank dataset

${ }^{\mathrm{b}}$ Data (average) for the period from 2011 to 2013

'Data for 2008

${ }^{\mathrm{d} D a t a}$ for 2010

eData for 2011

fData for 2012

${ }^{9}$ Data for 2013

hData (average) of 2011 and 2013

$P=0.031)$ and ageing rate $(\mathrm{B}=-0.059, P=0.009)$ were related to the prevalence of TCAM practitioner usage in model 1.2 and 1.3, respectively. In model 2 , for the entire sample, the unemployment rate was related to the prevalence of TCAM practitioner usage $(B=-0.044$, $P=0.027$ ). For men, the ageing rate was related to the 


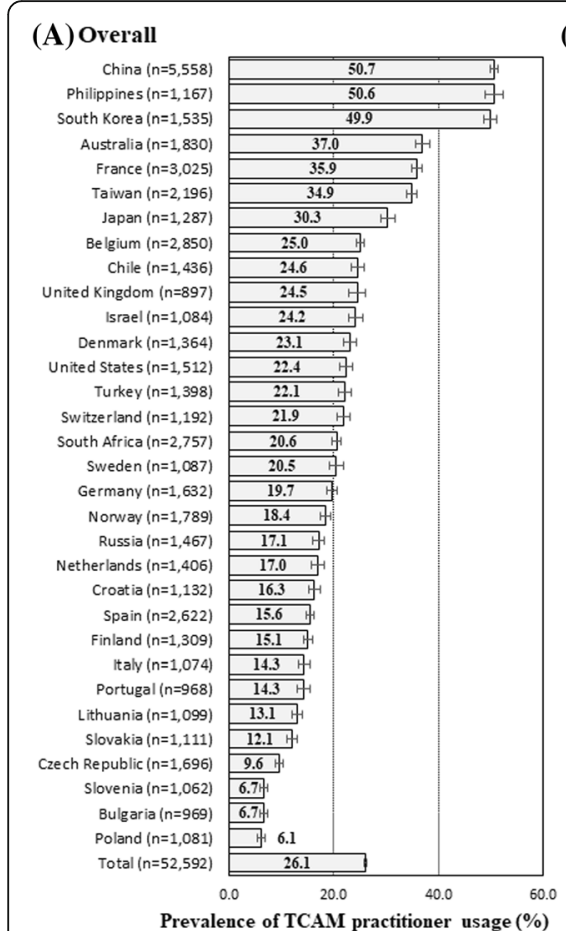

(B) Men

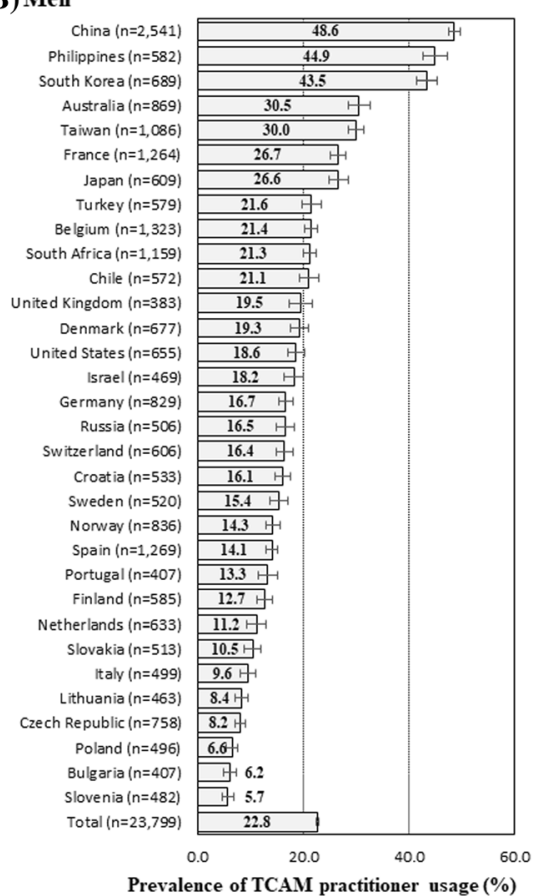

(C) Women

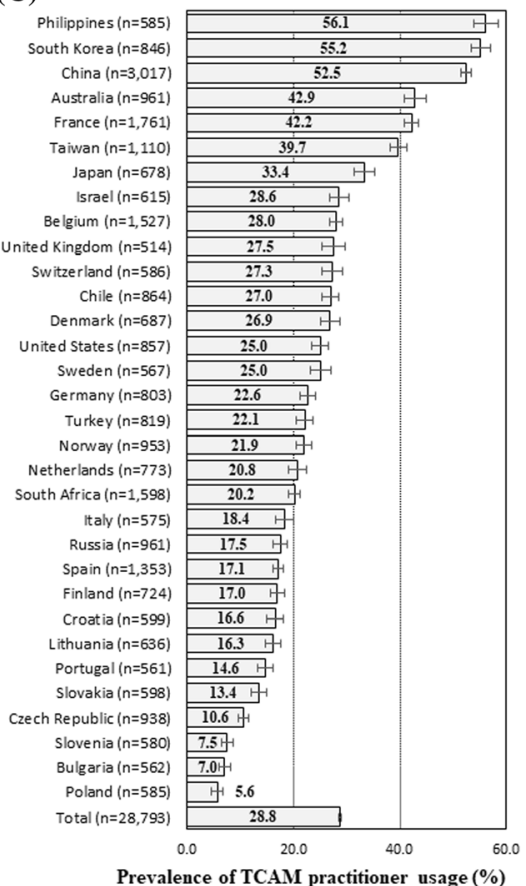

Fig. 2 The prevalence of TCAM practitioner usage among 32 countries. Prevalence of TCAM practitioner usage was stratified by country for (a) the Entire Sample, (b) Men, and (c) Women. Values in parentheses represent the sample size of each country

prevalence of TCAM practitioner usage in model 1.3 $(B=-0.061, P=0.009)$. However, for men, the Gini index $(B=0.032, P=0.050)$ and the unemployment rate $(\mathrm{B}=-0.038, P=0.054)$ were not related to the prevalence of TCAM practitioner usage in model 1.1 and 1.2, respectively. In model 2 , for men, the unemployment rate was related to the prevalence of TCAM practitioner usage ( $B=-0.042, P=0.039$ ). For women, the Gini index was not related to the prevalence of TCAM practitioner usage in model $1.1(\mathrm{~B}=0.0 .28, P=0.079)$. However, for women, the unemployment rate $(B=-0.043, P=0.025)$ and the ageing rate $(\mathrm{B}=-0.059, P=0.010)$ were related to the prevalence of TCAM practitioner usage in model 1.2 and 1.3 , respectively. In model 2 , for women, the unemployment rate was related to the prevalence of TCAM practitioner usage $(\mathrm{B}=-0.045, P=0.026)$.

\section{Discussion}

In this study, we found that the prevalence of TCAM practitioner usage varied across the 32 countries. We also found that the unemployment rate, as uncertainty in society, was associated with the prevalence of TCAM practitioner usage.

Employing an international social survey conducted between 2011 and 2013, this study was able to determine the prevalence of TCAM practitioner usage across 32 countries. We found that the prevalence of TCAM practitioner usage was high in Asian countries. This might be owing to popular traditional medicine practices in these countries, such as traditional Chinese medicine and Kampo medicine [10, 12, 20, 23]. Overall, the prevalence of TCAM usage in the present study tended to be lower than that found in previous research $[7,8,10]$, with an average of $26.1 \%$. Most previous surveys have included TCAM products and practitioners $[8,10,23]$. The ISSP survey, however, investigated the visits to an alternative/traditional/folk health care practitioner during the past 12 months as TCAM practitioner usage. Thus, the prevalence of TCAM usage in this study tended to be lower than that found in previous research. However, compared to a previous review on the prevalence of TCAM usage regarding visits to TCAM practitioners [7], the prevalence of TCAM usage in this study was not very low. Thus, we believe that, in terms of the prevalence of TCAM practitioner usage, the findings of this study are reasonable. We also found that the TCAM practitioner usage prevalence rate among women (28.8\%) was higher than that among men (22.8\%). These findings support previous studies showing the differences between men and women at an individual level [13-16]. Thus, we believe that the results at the social-structural level in this study are valid.

Previous research on the prevalence of and factors affecting TCAM usage has not focused on an international comparison. Rather, it has examined the impact of individual determinants on TCAM usage. 
Table 3 Associations with the prevalence of TCAM practitioner usage for total sample and by gender

\begin{tabular}{|c|c|c|c|c|c|c|c|}
\hline & $\begin{array}{l}\text { Prevalence of } \\
\text { TCAM } \\
\text { practitioner usage }\end{array}$ & $\begin{array}{l}\text { Prevalence of TCAM } \\
\text { practitioner usage } \\
\text { for men }\end{array}$ & $\begin{array}{l}\text { Prevalence of TCAM } \\
\text { practitioner usage for } \\
\text { women }\end{array}$ & $\begin{array}{l}\text { Gini } \\
\text { index }\end{array}$ & $\begin{array}{l}\text { Unemployment } \\
\text { rate }\end{array}$ & $\begin{array}{l}\text { Ageing } \\
\text { rate }\end{array}$ & $\begin{array}{l}\text { GDP } \\
\text { per } \\
\text { capita } \\
\end{array}$ \\
\hline \multirow{2}{*}{$\begin{array}{l}\text { Prevalence of TCAM practitioner usage } \\
\text { for total sample }\end{array}$} & \multirow[t]{2}{*}{1.000} & 0.963 & 0.977 & 0.314 & -0.549 & -0.373 & 0.165 \\
\hline & & $(<0.001)$ & $(<0.001)$ & $(0.085)$ & $(0.001)$ & $(0.039)$ & $(0.374)$ \\
\hline \multirow{2}{*}{$\begin{array}{l}\text { Prevalence of TCAM practitioner usage } \\
\text { for men }\end{array}$} & & 1.000 & 0.901 & 0.400 & -0.435 & -0.420 & 0.011 \\
\hline & & & $(<0.001)$ & $(0.026)$ & $(0.015)$ & $(0.019)$ & $(0.954)$ \\
\hline \multirow{2}{*}{$\begin{array}{l}\text { Prevalence of TCAM practitioner usage } \\
\text { for women }\end{array}$} & & & 1.000 & 0.237 & -0.610 & -0.299 & 0.269 \\
\hline & & & & $(0.199)$ & $(<0.001)$ & $(0.102)$ & (0.143) \\
\hline \multirow[t]{2}{*}{ Gini index } & & & & 1.000 & 0.159 & -0.417 & -0.557 \\
\hline & & & & & $(0.394)$ & $(0.020)$ & $(0.001)$ \\
\hline \multirow[t]{2}{*}{ Unemployment rate } & & & & & 1.000 & 0.211 & -0.422 \\
\hline & & & & & & $(0.254)$ & $(0.018)$ \\
\hline \multirow[t]{2}{*}{ Ageing rate } & & & & & & 1.000 & 0.376 \\
\hline & & & & & & & $(0.037)$ \\
\hline GDP per capita & & & & & & & 1.000 \\
\hline
\end{tabular}

Values in parentheses represent $P$-values

Table 4 Generalized linear model with the prevalence of TCAM practitioner usage controlled by GDP per capita $(N=31)$

\begin{tabular}{|c|c|c|c|c|c|c|c|c|c|c|c|c|}
\hline \multirow[t]{2}{*}{ Overall } & \multicolumn{3}{|c|}{ Model 1.1} & \multicolumn{3}{|c|}{ Model 1.2} & \multicolumn{3}{|c|}{ Model 1.3} & \multicolumn{3}{|c|}{ Model 2} \\
\hline & $\mathrm{B}$ & SE & $P$ value & $B$ & SE & $P$ value & $\mathrm{B}$ & SE & $P$ value & B & SE & $P$ value \\
\hline Intercept & 1.890 & 0.635 & $0.006^{* *}$ & 3.550 & 0.268 & $<0.001^{* * *}$ & 3.717 & 0.306 & $<0.001^{* * *}$ & 2.985 & 0.818 & $0.001^{* *}$ \\
\hline Gini index & 0.029 & 0.015 & 0.064 & & & & & & & 0.022 & 0.016 & 0.175 \\
\hline Unemployment rate & & & & -0.041 & 0.018 & $0.031^{*}$ & & & & -0.044 & 0.019 & $0.027^{*}$ \\
\hline Aging rate & & & & & & & -0.059 & 0.021 & $0.009^{* *}$ & -0.031 & 0.025 & 0.221 \\
\hline Deviance & 7.7 & & & 7.1 & & & 6.5 & & & 5.3 & & \\
\hline AIC & 237.3 & & & 234.8 & & & 232.0 & & & 229.3 & & \\
\hline \multicolumn{13}{|l|}{ Men } \\
\hline Intercept & 1.723 & 0.645 & $0.012^{* *}$ & 3.445 & 0.279 & $<0.001^{* * *}$ & 3.665 & 0.317 & $<0.001^{* * *}$ & 2.843 & 0.843 & $0.002^{* *}$ \\
\hline Gini index & 0.032 & 0.015 & 0.050 & & & & & & & 0.024 & 0.016 & 0.157 \\
\hline Unemployment rate & & & & -0.038 & 0.019 & 0.054 & & & & -0.042 & 0.019 & $0.039 *$ \\
\hline Aging rate & & & & & & & -0.061 & 0.022 & $0.009^{* *}$ & -0.033 & 0.026 & 0.207 \\
\hline Deviance & 7.8 & & & 7.6 & & & 6.7 & & & 5.4 & & \\
\hline AIC & 227.6 & & & 226.6 & & & 222.4 & & & 220.0 & & \\
\hline \multicolumn{13}{|l|}{ Women } \\
\hline Intercept & 1.999 & 0.642 & $0.004^{* *}$ & 3.620 & 0.269 & $<0.001^{* * *}$ & 3.759 & 0.307 & $<0.001^{* * *}$ & 3.104 & 0.827 & $<0.001^{* * *}$ \\
\hline Gini index & 0.028 & 0.015 & 0.079 & & & & & & & 0.021 & 0.016 & 0.211 \\
\hline Unemployment rate & & & & -0.043 & 0.018 & $0.025^{*}$ & & & & -0.045 & 0.019 & $0.026^{*}$ \\
\hline Aging rate & & & & & & & -0.059 & 0.021 & $0.010^{*}$ & -0.031 & 0.025 & 0.230 \\
\hline Deviance & 8.0 & & & 7.2 & & & 6.9 & & & 5.5 & & \\
\hline $\mathrm{AlC}$ & 245.3 & & & 242.0 & & & 240.1 & & & 237.6 & & \\
\hline
\end{tabular}

$B$ Coefficient

SE Standard error

AIC Akaike's Information Criterion

***: $p<0.001 ;{ }^{* *}: p<0.01 ;{ }^{*}: p<0.05$ 
Since questionnaires to determine whether participants use TCAM vary depending on the study context, it was difficult to accurately compare the prevalence of TCAM usage between countries. This current survey, however, found that the prevalence of TCAM practitioner usage varied greatly among the 32 target countries. Analyzing the international comparison survey data precisely showed the variations in the prevalence of TCAM usage among the target countries. The findings in this study show that the difference between the maximum and minimum prevalence rates among 32 countries was about 44 points for the entire sample. The difference was quite large among men and women. The difference among women was more prominent. This suggests that the utilization of TCAM varies widely from county to country, and that the unique characteristics of a country may be related to the prevalence of TCAM usage. The large difference between the maximum and minimum prevalence rates among women in comparison to those among men suggests that women might use TCAM considerably depending on the social context of the country.

We analyzed the relationship between the social structure of uncertainty - inequality, occupation, and population perspectives - and the prevalence of TCAM practitioner usage. According to the results of the generalized linear models with all variables on uncertainty in society, we found a negative relationship between the unemployment rate (i.e., the occupation perspective) and the prevalence of TCAM practitioner usage in the entire sample, for both men and women. This result suggests that uncertainty in employment might lead to people refraining from using TCAM as a consumption behavior. This may be because people consider TCAM as a kind of luxury, and so they cannot afford to use TCAM. In particular, as the TCAM usage in this study was defined as visits to an alternative/traditional/folk health care practitioner, rather than TCAM as products that people can easily obtain, TCAM usage might be a luxury for people in uncertain contexts with job insecurity. Therefore, people might not use TCAM to steadily cope with uncertainty in a society with job insecurity.

Furthermore, differences in the cost of using TCAM by country may be relevant to people for considering TCAM as a luxury. For example, in the United States, TCAM visits to practitioners of services such as acupuncture and Ayurveda are higher in out-of-pocket costs than TCAM products such as non-vitamin, nonmineral, and natural products [49]. Conversely, in Japan, where TCAM has been used traditionally, there is no significant difference between the costs of visits to TCAM practitioners such as acupuncture specialists and TCAM products such as Kampo; this is because individuals in Japan are reimbursed by health insurance for using these services and products [10]. In other words, in countries where the cost of TCAM is high, high unemployment rate may be related to lesser usage of TCAM. Based on these points, although this paper focused only on the social-structural factors of uncertainty in society, it will be necessary in future studies to explore how TCAM usage is institutionalized in the healthcare systems of each country, as well as to examine whether people can easily use TCAM in terms of cost.

The fact that people do not use TCAM may also indicate that people sacrifice their own health to cope with uncertainty in society. We hypothesized that the social structure of uncertainty in society is positively related to TCAM usage, and speculated that people will use TCAM more to maintain their health in an uncertain society. However, the findings did not confirm this hypothesis. Therefore, we argue that people rely on steady coping behaviors to deal with uncertainty in a society with job insecurity, instead of using TCAM (as they may consider it to be a luxury). Regarding the relationship between job insecurity and health status, previous researchers have indicated that people with job insecurity are not healthy $[40,41,50]$. Thus, based on these findings, it appears that not using TCAM may lead to a deterioration of the health status of socially disadvantaged people in an uncertain society with job insecurity. Additionally, we found that only the unemployment rate was related to TCAM practitioner usage, and not the Gini index or ageing rate. This may be because people consider job insecurity as an easily-understood uncertain social context, rather than income inequality and the ageing population. It would be reasonable to consider that uncertainty in terms of employment may lead to people refraining from using TCAM as it is seen as a luxury, given that the middle-aged population, who are active workers, tended to use TCAM frequently $[16,51]$. As this study has shown that an increase in the unemployment rate is negatively related to TCAM usage, especially visits to alternative/traditional/ folk health care practitioners, it would be appropriate to take economic measures for promoting TCAM usage. As a previous study has shown that the health of the population suffers after economic recession [38], economic measures may be effective for health policy regarding TCAM usage.

Furthermore, and interestingly, it appears that the pathway of the impact of unemployment rate on TCAM practitioner usage differs slightly between men and women. For women, the effect of unemployment rate on TCAM practitioner usage was found to be consistent from model 1.2 (i.e., the model adopting only the unemployment rate controlled by GDP per capita) to model 2 (i.e., the model adopting all variables). However, for men, although unemployment rate had no significant 
effect on TCAM practitioner usage in model 1.2, the effect of unemployment rate does appear in model 2 . Therefore, this finding partly supports the hypotheses that the impact of an uncertain society on TCAM usage varies between genders. The findings suggest that, for men, it would be reasonable to consider that unemployment rate influences the prevalence of TCAM usage in relation to other social-structural factors of uncertainty in society. Certain economic measures for men against unemployment are necessary, considering the influences of income inequalities and ageing population.

Regarding the social-structural variables of uncertainty in society other than unemployment rate, we were unable to determine the effect of the Gini index (i.e., income inequality) on TCAM usage in the form of visits to alternative/traditional/folk health care practitioners. Previous research has shown that people living in countries with large income inequalities have lower population health than those in countries with low income inequalities [37]. Furthermore, a previous study reported a significant relationship between TCAM usage, excellent health, and health improvement [52]. With respect to the pathways from income inequality to health, studies have shown that psychosocial factors, such as social capital and trust, mediate the relationship [53, 54]. Thus, psychosocial factors could mediate the relationship between income inequality and TCAM usage. However, as this is beyond the scope of this study, and considering the impact of income inequalities on TCAM usage, it will be necessary to consider psychosocial factors as well in future study.

Additionally, regarding the ageing rate, we found that although ageing rate had a significantly negative effect on TCAM practitioner usage in model 1.3 (i.e., the model adopting only the ageing rate controlled by GDP per capita), the effect of ageing rate disappeared in the model that adopted all variables (model 2). This finding may also be involved in the influence of other socialstructural factors of uncertainty in society. The results of the correlation analysis showed that the ageing rate was moderately correlated with the Gini index and GDP per capita. Previous studies have reported that population ageing was associated with income inequalities [55]. Thus, population ageing is strongly associated with social structural elements such as income inequalities. Therefore, we believe that population ageing is not associated with TCAM usage directly when other socialstructural factors of uncertainty in society are involved. In that sense, even while considering the other social structural factors,, job insecurity was shown to be more important factors underlying TCAM usage at a national level.

The study showed that CAM usage is related to the occupational perspective (especially job insecurity) in social structure. For future research and policy recommendations, it is necessary to examine the occupational perspectives in social structure while considering the macro-level factors underlying TCAM usage. Since many countries do not have any health policy that takes TCAM into account [56], it will be necessary to take job insecurity in the social structure into account while designing future health policies related to TCAM.

There are some limitations in the present study. First, we analyzed the relationship between uncertainty in society and the prevalence of TCAM usage at the macro level to understand its global prevalence among 32 countries. However, examining the effect of social structure of uncertainty on TCAM usage at the individual level will be useful too. By understanding the factors underlying TCAM usage and by taking into consideration the influence of the individual and macro levels, it will be possible to clarify the more essential factors underlying the use of TCAM. Moreover, we suggested the effects of economic measures when arguing from an employment perspective. Previous research has shown that economic measures at the national level have an effect on population health [57]. However, another study has shown that economic incentives are not always related to people's motivation to improve their own health [58]. Thus, there may be limits to the economic measures at the national level. Based on these points, it will be necessary to survey the trends of economic measures in each country and to explore how such measures relate to the relationship between unemployment rate and TCAM usage. In addition, the finding of the present study suggested that not using TCAM may lead to deterioration of health status in an uncertain society. However, in western countries, not all people opt for TCAM usage even if they have a health complaint and can afford it [59]. Thus, considering the relationship between TCAM usage, health, and economic conditions, the impact of uncertainty in society on TCAM usage should be elucidated. We also analyzed the cross-sectional relationship among factors in the study using the ISSP data. As response rate tends to be low in countries where postal surveys were conducted, the data may be biased. However, we calculated the age-standardized prevalence of TCAM practitioner usage to take into account the bias, such as the age structure, of each country. Furthermore, because social structures of uncertainty change over time, it will be necessary to reexamine the longitudinal effects of social structure of uncertainty on TCAM usage. Since research on the relationship between social structure of uncertainty and TCAM usage is scarce, solving these limitations in future studies will serve to clarify the relationship. Finally, the definition of TCAM in the present study was limited to visits to alternative/traditional/folk health care 
practitioners. Generally, the definition of TCAM does not only include these practices, but also products such as supplements. The most commonly used TCAM products is supplements $[8,10,23]$. Furthermore, the definitions of TCAM in a local context are crucial for comparisons. Moreover, the definition of TCAM in the present study includes both complementary and traditional therapies. Thus, although the impact of uncertainty in society on the use of TM and CAM could be different, the difference might be overlooked. This difference should be considered when examining the effect of social structure of uncertainty on TCAM usage not only at the social level but also at the individual level. Therefore, in future studies, it will be important to examine the relationship between uncertain social structure and the use of TCAM including supplements, while considering not only the definition of TCAM in the local contexts but also the difference between TM and CAM.

\section{Conclusions}

At the social level, the prevalence of TCAM usage regarding visits to practitioners among the 32 target countries showed great variations. The usage of TCAM regarding visits to practitioners was shown to be related to the social-structural factors of uncertainty. Job insecurity decreased TCAM usage regarding visits to practitioners. These findings suggest that it is necessary to consider the social-structural factors of uncertainty in society when designing health policies related to TCAM.

\section{Additional file}

Additional file 1: Table $\mathbf{S}$ 1. The process of TCAM practitioner usage age and gender exclusion in 32 countries. The process in which TCAM practitioner usage, age and sex were excluded in each country is shown. (DOCX $16 \mathrm{~kb}$ )

\section{Abbreviations}

CAM: Complementary and Alternative Medicine; GDP: Gross Domestic Product; ISSP: International Social Survey Programme; $r_{s}$ : Spearman's rho; TCAM: Traditional, Complementary and Alternative Medicine; TM: Traditional Medicine

\section{Acknowledgments}

We would like to express our deepest gratitude to Keiko Yukawa and Kiichiro Tsutani.

\section{Authors' contributions}

JM had the idea for the study, participated in its design, performed the statistical analysis, and drafted the manuscript. RI helped in interpreting the results and in revising the manuscript. AS and YM helped in interpreting the results. IA and TH critically interpreted the result. YK edited the manuscript. All authors read and approved the final manuscript.

\section{Funding}

This work was supported by the Japan Agency for Medical Research and Development (AMED) (Research Project for Improving Quality in Healthcare and Collecting Scientific Evidence on Integrative Medicine) [Grant number: 16lk0310024j0101, 17lk0310039j0001]. The funders had no role in study design; in the collection, analysis and interpretation of data; in the writing of the articles; and in the decision to submit it for publication.

\section{Availability of data and materials}

The datasets generated and/or analyzed during the current study are available in the gesis repository (https://doi.org/10.4232/1.12252) and the World Bank Open Data (http://data.worldbank.org/).

\section{Ethics approval and consent to participate}

The ISSP General Assembly approved questions based on their scientific merit, sociopolitical relevance and ethical appropriateness. All participating countries had to comply with the given legal requirements in each country. Before depositing data to the ISSP Archive national ISSP data are anonymized so that individual survey participants cannot be identified (see International Social Survey Programme ethical statement on http://www.issp.org). With regard to World Bank data, no human subjects are involved.

\section{Consent for publication}

Not applicable.

\section{Competing interests}

The authors declare that they have no competing interests.

\section{Author details}

${ }^{1}$ Department of Health Care Services Management, Nihon University School of Medicine, 30-1, Oyaguchikami-cho, Itabashi, Tokyo 173-8610, Japan. ${ }^{2}$ Department of Pediatrics and Child Health, Nihon University School of Medicine, 30-1, Oyaguchikami-cho, Itabashi, Tokyo 173-8610, Japan. ${ }^{3}$ Department of Kampo Medicine, Nihon Pharmaceutical University, 10281, Komuro, Ina, Kita-adachi, Saitama 362-0806, Japan. ${ }^{4}$ Department of Information Science, Faculty of Science, Toho University, 2-2-1, Miyama, Funabashi, Chiba 274-8510, Japan.

Received: 1 February 2019 Accepted: 29 August 2019

Published online: 09 September 2019

\section{References}

1. Institute of Medicine. Complementary and alternative medicine in the United States. Washington DC: National Academies Press; 2005.

2. Eisenberg DM, Davis RB, Ettner SL, Appel S, Wilkey S, Van Rompay M, Kessler RC. Trends in alternative medicine use in the United States, 1990-1997: results of a follow-up national survey. JAMA. 1998;280(18):1569-75.

3. Frass M, Strassl RP, Friehs $H$, Mullner M, Kundi M, Kaye AD. Use and acceptance of complementary and alternative medicine among the general population and medical personnel: a systematic review. Ochsner J. 2012:12(1):45-56.

4. Ong C-K, Bodeker G, Grundy C, Burford G, Shein K. WHO global atlas of traditional, complementary and alternative medicine. Kobe: WHO Centre for Health Development; 2005.

5. Peltzer K, Pengpid S. Prevalence and determinants of traditional, complementary and alternative medicine provider use among adults from 32 countries. Chin J Integr Med. 2018;24(8):584-90.

6. Peltzer K, Pengpid S, Puckpinyo A, Yi S, Vu Anh L. The utilization of traditional, complementary and alternative medicine for non-communicable diseases and mental disorders in health care patients in Cambodia, Thailand and Vietnam. BMC Complement Altern Med. 2016;16(1):92.

7. Harris PE, Cooper KL, Relton C, Thomas KJ. Prevalence of complementary and alternative medicine (CAM) use by the general population: a systematic review and update. Int J Clin Pract. 2012:66(10):924-39.

8. Clarke TC, Black LI, Stussman BJ, Barnes PM, Nahin RL. Trends in the use of complementary health approaches among adults: United States, 2002-2012. Natl Health Stat Rep. 2015;(79):1-16

9. Eardley S, Bishop FL, Prescott P, Cardini F, Brinkhaus B, Santos-Rey K, Vas J, von Ammon K, Hegyi G, Dragan S, et al. A systematic literature review of complementary and alternative medicine prevalence in EU. Forsch Komplementmed (2006). 2012;19(Suppl 2):18-28

10. Yamashita H, Tsukayama H, Sugishita C. Popularity of complementary and alternative medicine in Japan: a telephone survey. Complement Ther Med. 2002;10(2):84-93.

11. Baek SH, Oh JW, Shin JS, Lee J, Lee YJ, Kim MR, Ahn YJ, Choi A, Park KB, Shin $B C$, et al. Long term follow-up of cervical intervertebral disc herniation 
inpatients treated with integrated complementary and alternative medicine: a prospective case series observational study. BMC Complement Altern Med. 2016;16:52.

12. Shih CC, Liao CC, Su YC, Tsai CC, Lin JG. Gender differences in traditional Chinese medicine use among adults in Taiwan. PLoS One. 2012;7(4):e32540.

13. Ishizaki N, Yano T, Kawakita K. Public status and prevalence of acupuncture in Japan. Evid Based Complement Alternat Med. 2010;7(4):493-500.

14. Yeh YH, Chou YJ, Huang N, Pu C, Chou P. The trends of utilization in traditional Chinese medicine in Taiwan from 2000 to 2010: A populationbased study. Medicine (Baltimore). 2016;95(27):e4115.

15. Kantor ED, Rehm CD, Du M, White E, Giovannucci EL. Trends in dietary supplement use among US adults from 1999-2012. JAMA. 2016;316(14):1464-74.

16. Bishop FL, Lewith GT. Who uses CAM? A narrative review of demographic characteristics and health factors associated with CAM use. Evid Based Complement Alternat Med. 2010;7(1):11-28.

17. Shih CC, Su YC, Liao CC, Lin JG. Patterns of medical pluralism among adults: results from the 2001 National Health Interview Survey in Taiwan. BMC Health Serv Res. 2010;10:191.

18. Ock SM, Hwang SS, Lee JS, Song CH, Ock CM. Dietary supplement use by south Korean adults: data from the national complementary and alternative medicine use survey (NCAMUS) in 2006. Nutr Res Pract. 2010;4(1):69-74.

19. Upchurch DM, Rainisch BW. A sociobehavioral wellness model of acupuncture use in the United States, 2007. J Altern Complement Med. 2014;20(1):32-9.

20. Shih CC, Lin JG, Liao CC, Su YC. The utilization of traditional Chinese medicine and associated factors in Taiwan in 2002. Chin Med J (Engl). 2009; 122(13):1544-8.

21. Ock SM, Choi JY, Cha YS, Lee J, Chun MS, Huh CH, Lee SY, Lee SJ. The use of complementary and alternative medicine in a general population in South Korea: results from a national survey in 2006. J Korean Med Sci. 2009;24(1):1-6.

22. Birdee GS, Wayne PM, Davis RB, Phillips RS, Yeh GY. T'ai chi and qigong for health: patterns of use in the United States. J Altern Complement Med. 2009;15(9):969-73.

23. Misawa J, Ichikawa R, Shibuya A, Maeda Y, Hishiki T, Kondo Y. Social determinants affecting the use of complementary and alternative medicine in Japan: an analysis using the conceptual framework of social determinants of health. PLoS One. 2018;13(7):e0200578.

24. Misawa J. Effects of psychosocial factors on use of complementary and alternative medicine. J Health Welf Stat. 2011;58(6):1-7 (In Japanese)

25. Van den Bulck J, Custers K. Belief in complementary and alternative medicine is related to age and paranormal beliefs in adults. Eur J Public Health. 2010;20(2):227-30.

26. Hwang JH, Han DW, Yoo EK, Kim WY. The utilisation of complementary and alternative medicine (CAM) among ethnic minorities in South Korea. BMC Complement Altern Med. 2014;14:103.

27. Bardia A, Nisly NL, Zimmerman MB, Gryzlak BM, Wallace RB. Use of herbs among adults based on evidence-based indications: findings from the National Health Interview Survey. Mayo Clin Proc. 2007;82(5):561-6.

28. Sevilla-Dedieu C, Kovess-Masfety V, Haro JM, Fernandez A, Vilagut G, Alonso J. Seeking help for mental health problems outside the conventional health care system: results from the European study of the epidemiology of mental disorders (ESEMeD). Can J Psychiatry. 2010;55(9):586-97.

29. Johnson PJ, Kozhimannil KB, Jou J, Ghildayal N, Rockwood TH. Complementary and alternative medicine use among women of reproductive age in the United States. Womens Health Issues. 2016;26(1):40-7.

30. Gardiner P, Graham R, Legedza AT, Ahn AC, Eisenberg DM, Phillips RS. Factors associated with herbal therapy use by adults in the United States. Altern Ther Health Med. 2007;13(2):22-9.

31. Barner JC, Bohman TM, Brown CM, Richards KM. Use of complementary and alternative medicine for treatment among African-Americans: a multivariate analysis. Res Social Adm Pharm. 2010;6(3):196-208.

32. Wilkinson GR. The impact of inequality. New York: New York Press; 2005.

33. Gale N. The sociology of traditional, Complementary and Alternative Medicine. Sociol Compass. 2014;8(6):805-22.

34. Kemppainen LM, Kemppainen T, Reippainen JA, Salmenniemi ST, Vuolanto PH. Use of complementary and alternative medicine in Europe: health-related and sociodemographic determinants. Scand J Public Health. 2018:46(4):448-55.

35. Beck U. Riskogesellschaft: Auf dem Weg in eine andere Moderne. Berlin: Suhrkamp Verlag; 1986

36. Wilkinson I. Anxiety in a risk society. London: Routledge; 2001.
37. Pickett KE, Wilkinson RG. Income inequality and health: a causal review. Soc Sci Med. 2015:128:316-26.

38. Kondo N, Subramanian SV, Kawachi I, Takeda Y, Yamagata Z. Economic recession and health inequalities in Japan: analysis with a national sample, 1986-2001. J Epidemiol Community Health. 2008;62(10):869-75.

39. Misawa J, Ichikawa R, Shibuya A, Maeda Y, Hishiki T, Kondo Y. The prevalence of mental distress before the great East Japan earthquake and the associated impact of an aged society: an ecological study. PLoS One. 2018;13(9):e0203985.

40. Rajani NB, Giannakopoulos G, Filippidis FT. Job insecurity, financial difficulties and mental health in Europe. Occup Med (Lond). 2016:66(8):681-3.

41. Haines VA, Godley J, Hawe P, Shiell A. Socioeconomic disadvantage within a neighborhood, perceived financial security and self-rated health. Health Place. 2009;15(1):383-9.

42. Ek S. Gender differences in health information behaviour: a Finnish population-based survey. Health Promot Int. 2013;30(3):736-45.

43. Rice RE. Influences, usage, and outcomes of internet health information searching: multivariate results from the pew surveys. Int J Med Inform 2006;75(1):8-28.

44. Hill TD, Needham BL. Rethinking gender and mental health: a critical analysis of three propositions. Soc Sci Med. 2013;92:83-91.

45. Slopen N, Williams DR, Fitzmaurice GM, Gilman SE. Sex, stressful life events, and adult onset depression and alcohol dependence: are men and women equally vulnerable? Soc Sci Med. 2011;73(4):615-22.

46. ISSP Research Group. International Social Survey Programme: Health and Health Care - ISSP 2011. In: ZA5800 Data file Version 3.0.0 edn: GESIS Data Archive. Cologne; 2015.

47. The World Bank: World Bank Open Data. 2017. http://data.worldbank.org/. Accessed 15 Mar 2018

48. Faraway JJ. Extending the linear model with R. generalized linear, mixed effects and nonparametric regression models. Boca Raton: Chapman \& Hall/ CRC 2006; 2006

49. Nahin RL, Barnes PM, Stussman BJ, Bloom B. Costs of complementary and alternative medicine (CAM) and frequency of visits to CAM practitioners: United States. Natl Health Stat Rep. 2007;2009(18):1-14.

50. Misawa J. A study on the relationship between future financial insecurity and self-rated health:analysis of using JGSS-2008 data. JGSS Research Series. 2010;10:123-35 (In Japanese with English abstract).

51. Barnes PM, Bloom B, Nahin RL. Complementary and alternative medicine use among adults and children: United States. Natl Health Stat Rep. 2007; 2008(12):1-23.

52. Nguyen LT, Davis RB, Kaptchuk TJ, Phillips RS. Use of complementary and alternative medicine and self-rated health status: results from a national survey. J Gen Intern Med. 2011;26(4):399-404.

53. Layte R. The association between income inequality and mental health: testing status anxiety, social capital, and neo-materialist explanations. Eur Sociol Rev. 2011;28(4):498-511.

54. Elgar FJ. Income inequality, trust, and population health in 33 countries. Am J Public Health. 2010;100(11):2311-5.

55. Dong $Z$, Tang $C$, Wei $X$. Does population aging intensify income inequality? Evidence from China. J Asia Pac Econ. 2018;23(1):66-77.

56. Wiesener S, Falkenberg T, Hegyi G, Hok J, Roberti di Sarsina P, Fonnebo V. Legal status and regulation of complementary and alternative medicine in Europe. Forsch Komplementmed (2006). 2012;19(Suppl 2):29-36.

57. Takano T, Nakamura K. The national financial adjustment policy and the equalisation of health levels among prefectures. J Epidemiol Community Health. 2001:55(10):748-54

58. Liu T, Volpp KG, Asch DA, Zhu J, Wang W, Wu R, Troxel AB, Finnerty DD, Hoffer K, Shea JA. The association of financial incentives for low density lipoprotein cholesterol reduction with patient activation and motivation. Prev Med Rep. 2019:14:100841

59. Kristoffersen AE, Stub T, Musial F, Fonnebo V, Lillenes O, Norheim AJ. Prevalence and reasons for intentional use of complementary and alternative medicine as an adjunct to future visits to a medical doctor for chronic disease. BMC Complement Altern Med. 2018;18(1):109.

\section{Publisher's Note}

Springer Nature remains neutral with regard to jurisdictional claims in published maps and institutional affiliations. 